\title{
Journal of Homosexuality
}

\section{Community-Based Resistance Strategies among a Group of Trans Women in Lima, Peru during the COVID-19 Pandemic}

\section{Diego Garcia-Rabines \& Bruno Bencich}

To cite this article: Diego Garcia-Rabines \& Bruno Bencich (2021) Community-Based Resistance Strategies among a Group of Trans Women in Lima, Peru during the COVID-19 Pandemic, Journal of Homosexuality, 68:4, 663-672, DOI: 10.1080/00918369.2020.1868189

To link to this article: https://doi.org/10.1080/00918369.2020.1868189

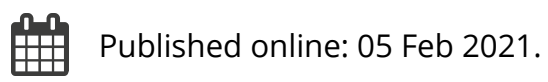

Submit your article to this journal $\pi$

III Article views: 337

Q View related articles ¿

View Crossmark data $־$

Citing articles: 1 View citing articles ¿ð 


\title{
Community-Based Resistance Strategies among a Group of Trans Women in Lima, Peru during the COVID-19 Pandemic
}

\author{
Diego Garcia-Rabines, BA (D) and Bruno Bencich, BA (D) \\ aGrupo de Investigación en Comunicación y Salud, Instituto de Investigación Científica, y Facultad de \\ Psicología, Universidad de Lima, Lima, Perú; ' ${ }^{\circ}$ Asociación para la Investigación en Inclusión y Diversidad \\ (INCIDE Perú), Lima, Perú
}

\begin{abstract}
This study explores the community-based strategies that a group of trans women living in Lima, Peru, employed to resist the negative impact of the COVID-19 pandemic on their wellbeing. Data was collected through participant observation and focus group discussions during the implementation of a social aid campaign targeted to this population and analyzed through reflexive theoretical thematic analysis. Resistance strategies were understood as forms of social capital grounded in relations of support and connectedness. Results underscored the importance of social cohesion to ameliorate increasing levels of precarity, community leaders as key for linking trans women across different networks, and unified efforts of social groups who share values to influence institutional power. The analysis also captured barriers and challenges that could hinder the development and articulation of social capital. Fostering trust relations and community-organization should be fundamental components for advocacy programs that seek to support the trans women community.
\end{abstract}

\section{KEYWORDS}

Trans women; COVID-19;

Peru; social capital; community strategies; precarity; resistance

Gender-based systemic and institutionalized discrimination interlocks with a set of social categories (e.g., racialization, migrant status, poverty, disenfranchisement, HIV seropositive status) to configure a particularly vulnerable situation for trans women ${ }^{1}$ in Peru (Salazar et al., 2016). Amidst this context, the mandatory social distancing and mobility restrictions implemented by the Peruvian government in response to the COVID-19 pandemic endangered trans women's capacity to sustain their lives, as most of them rely on sex-work and/or other manners of informal employment as their main source of income (Silva Santisteban et al., 2012). Additionally, there is an absence of institutional support for trans people from government officials (Alvarez et al., 2020), who even implemented a temporary gender-based mobility restriction that stipulated different days for "men" and "women" to circulate in public spaces (Supreme Decree 057, 2020). This measure directly affected the trans population as there is no legal recognition of their gender identities (Alvarez et al.,

CONTACT Diego Garcia-Rabines diego.garcia.rabines@gmail.com $\mathbf{\theta}$ Instituto de Investigación Científica, Universidad de Lima, Av. Javier Prado Este 4600, Lima 33, Perú. 
2020), exposing them to potential violence from law enforcement officials, who were in charge of implementing this regulation and have had a historical role as agents of institutionalized transphobia (Oporto, 2018).

Previous literature has reported on the importance of community-level strategies and social connections for mitigating the negative impact of social vulnerabilities among trans women in Peru (Clark et al., 2020; Maiorana et al., 2016; Perez-Brumer et al., 2017). These strategies can be understood through the concept of social capital, which refers to the resources nested in a community's networks and relations of trusting and cooperation with each other (bonding social capital), their connections with members of different groups who strive for compatible ends (bridging social capital) and with broader institutions across power differentials (linking social capital) (Szreter \& Woolcock, 2004).

During the pandemic, social capital was leveraged by the trans women community and LGBT+ organizations through a social media campaign called \#DonativoTrans. This initiative aimed to support the basic needs of 150 trans women living in nine casonas ${ }^{2}$-referred as trans-houses (casas trans) during the campaign - in Lima Centro by collecting donations such as food, money, or essentials that could be delivered to them, as well as coordinating with the lideresas (trans women who were leaders of each house) to offer support and advice on their proposed measures. To achieve this aim, the campaign capitalized not only on an existing network of trans women and community leaders, but also on collaborative relationships with other organizations (e.g., LGBT+ owned businesses, public entities, and media outlets) that were established to ensure its sustainability. Nevertheless, consistent efforts were made to position the trans women's experiences, needs, and decisions as priorities, thus the role of these organizations was to help provide the conditions for them to resist adversity under their own terms.

This study uses social capital as a theoretical framework to understand the community-based strategies these women employed to support each other and resist the negative impact the pandemic has had on their wellbeing. Using a qualitative methodology, it aimed to examine how forms of social support, community leadership, and inter-group relationships can be mobilized as a means of resistance to social vulnerabilities and failing infrastructural conditions.

\section{Methodology}

A critical and reflexive framework informed by feminist standpoint theory (Haraway, 1988) and transgender studies (Namaste, 2000, 2009) underpinned the methodology. Authors employed researcher reflexivity (Speed, 2008) to acknowledge how their positionality as non-trans identified individuals, their middle-class backgrounds, and roles as academics/activists configured a power 
imbalance in relation to the study subjects. Additionally, they reflected on the importance of presenting trans women as active subjects and for their "experiences, perceptions, and needs ... [to] occupy a central component of the research" (Namaste, 2000, p. 48).

The ethics committee of the Faculty of Psychology of the University of Lima approved this study. Additionally, to assure a participatory research paradigm, informed consent was given by the lideresas and an informal meeting was held with ten of them to discuss the study's relevance to their community. Data were collected through participant observation and focus group discussions by the second author, who was one of the coordinators of the \#DonativoTrans campaign and had daily communication with eleven lideresas and visited trans-houses once a week during the 108 days that the campaign lasted. For this study, a total of ten observations/visits (seven during and three after the campaign ended) were made to five different houses. The dual role of researcher and activist reduced the intrusiveness of observation and created opportunities to hear trans women's stories through informal conversations. A total of seven lideresas and four trans women who also lived in the houses participated in these informal interviews $(n=11)$. A narrative recount of observations was used to elaborate an interview guide aimed at exploring trans women's community organization during the pandemic. From this pool of eleven participants, six trans women (four lideresas and two trans women from the community) took part of two focus groups (each with a 30minute duration) conducted by the second author in Spanish.

Observational data and focus group transcripts were analyzed together by the lead author using reflexive theoretical thematic analysis to generate and report recurring themes within the data (Braun \& Clarke, 2006, 2019). Theoretical thematic analysis involves coding for a specific research question that is driven in part by theory and, therefore, is more deductive than a fully inductive approach (Braun \& Clarke, 2006). Following Braun and Clarke's method, transcripts of the focus groups and informal interviews were read by both authors to gain familiarity with the data and discuss researcher's positionality. Then, the first author generated codes and collated them with data excerpts, using the observational data to better contextualize the interviews. Codes were clustered within themes considerably informed by social capital theory. During the analysis phase, contact was kept with the lideresas through visits to transhouses and telephone conversations to clarify information and gather additional data, underscoring the iterative quality of the analysis. Both authors discussed and revised the final set of themes and an analytic narrative was constructed.

\section{Results}

The analytic process generated an overarching theme that understood the resistance strategies employed by trans women as grounded in networks 
Table 1. Overview of main themes and illustrative quotes from focus groups and informal interviews $(\mathrm{n}=11)$.

\begin{tabular}{|c|c|c|}
\hline Main Themes & No. & Illustrative quote \\
\hline \multirow[t]{9}{*}{$\begin{array}{l}\text { Community organization and } \\
\text { solidarity }\end{array}$} & 1 & $\begin{array}{l}\text { "... they sent } 200 \text { soles to buy rice and we distributed it equally } \\
\text { among all the girls" }\end{array}$ \\
\hline & 2 & $\begin{array}{l}\text { "The first days it was tough, but with time we started gathering, } \\
\text { played bingo, gossiped and laughed together" }\end{array}$ \\
\hline & 3 & $\begin{array}{l}\text { "I've been getting along [with her housemates] ... because we know } \\
\text { each other better ... now it's different" }\end{array}$ \\
\hline & 4 & $\begin{array}{l}\text { "... I was afraid of the police because they were saying we could get } \\
\text { fined or be arrested [during the gender-based mobility restriction]" }\end{array}$ \\
\hline & 5 & "For safety, we would go [to the market] in pairs" \\
\hline & 6 & $\begin{array}{l}\text { "I've learned at the YMCA about our rights ... if you know your rights } \\
\text { you can face the police and defend yourself" }\end{array}$ \\
\hline & 7 & $\begin{array}{l}\text { "... the state that violates [trans women rights] by not considering } \\
\text { a gender identity law ... and this creates a lot of difficulties for us" }\end{array}$ \\
\hline & 8 & $\begin{array}{l}\text { "... they didn't like the food and wanted to eat meals from their } \\
\text { regions" }\end{array}$ \\
\hline & 9 & "At my house ... now everyone is looking up for themselves" \\
\hline \multirow[t]{8}{*}{ Legitimizing leadership } & 10 & $\begin{array}{l}\text { ".. I have more time working in a corner so a new girl comes and } \\
\text { I can help telling her we could work together on my corner" }\end{array}$ \\
\hline & 11 & $\begin{array}{l}\text { "The one that protects you ... if you have a problem you can trust } \\
\text { her ... so she is called madre, as a way of showing gratitude and } \\
\text { affection" }\end{array}$ \\
\hline & 12 & "They see me as a responsible person and they trust me ..." \\
\hline & 13 & "All my daughters voted for me to be the lideresa of the house" \\
\hline & 14 & $\begin{array}{l}\text { "... all the girls chose me to be the lideresa because I took the time to } \\
\text { do everything ... to bring the donations, the groceries, the meals } \\
\text { for each girl" }\end{array}$ \\
\hline & 15 & $\begin{array}{l}\text { "... would make a video recording showing all the groceries ... asked } \\
\text { for receipts ... to avoid misunderstandings" }\end{array}$ \\
\hline & 16 & $\begin{array}{l}\text { "When they delivered me the donations, for them [other trans } \\
\text { women] not to say that I was keeping stuff, I left all outside and } \\
\text { they looked at everything that came" }\end{array}$ \\
\hline & 17 & $\begin{array}{l}\text { "The girls sometimes said that they [Lideresas] were keeping the } \\
\text { money or buying more for themselves" }\end{array}$ \\
\hline \multirow[t]{3}{*}{$\begin{array}{l}\text { Bridging relationships in the LGBT+ } \\
\text { community and beyond }\end{array}$} & 18 & $\begin{array}{l}\text { "The press has made a minimum job to make visible the situation of } \\
\text { trans people during the pandemic" }\end{array}$ \\
\hline & 19 & $\begin{array}{l}\text { "We feel uncomfortable being called men [by the media] because we } \\
\text { identify as women." }\end{array}$ \\
\hline & 20 & $\begin{array}{l}\text { "I want the report to be serious because they usually lean toward } \\
\text { mockery." }\end{array}$ \\
\hline
\end{tabular}

of support, cohesion, community leadership, and overall exercise of collective agency. This is further developed across the following three main themes (Table 1).

\section{Community organization and solidarity}

This theme captured how trans women leveraged community relationships and social cohesion to resist increasing precarity, as well as addressing potential barriers to community organizing. For instance, to cope with the shortage of resources, trans women engaged in organizing strategies based on solidarity: equal distribution of tangible aid (Quote 1) and the organization of ollas comunes (communal pots): meals prepared by combining the houses' produce. Additionally, stay-at-home measures significantly altered social dynamics that 
led to trans women sharing more time and activities with one another, which helped them deal with feelings of boredom and strengthened social connections (Quotes 2 \& 3).

Social cohesion was also leveraged by trans women to resist institutionalized violence through community organization and knowledge sharing. Government measures exacerbated existing intersectional discrimination toward trans individuals, which made occupying public spaces potentially more dangerous (Quote 4). To cope with this reality, trans women reported going in pairs or groups to the market as a buffer against possible discrimination (Quote 5). Additionally, trans women employed groups in messaging apps to disseminate a social media initiative that called for trans people to record discrimination acts and share the videos on social media. It is relevant to highlight that, when asked, the lideresas could not point out who started this initiative, but inferred that multiple members of the community started sharing it, which underscores the importance of knowledge sharing networks. The initiative led to video recordings showing discriminatory acts to reach mainstream media outlets, which ignited political debates about trans-rights and a revision of the police department policies regarding trans individuals ("PNP rechaza discriminación: sancionarán a los agentes que intervinieron a mujeres trans," 2020). Trans women were also able to promote civic literacy to help their community face police discrimination, while concurrently creating visibility about the necessity of a gender-identity protection law (Quotes $6 \& 7$ ).

Potential barriers to community organizing were identified. For instance, cultural differences regarding food choices challenged the organization of communal pots, thus some trans women started to prepare meals individually or by groups formed based on Peru's main geographic regions (Coastal, Andean, and Amazonian regions) (Quote 8). Additionally, as mobility restrictions were reduced and the campaign ended, social interactions diminished in some houses because trans women started to work again and regained an income. Thus, they began spending less time at their houses or withdrawing from the community-organized meals (Quote 9).

\section{Legitimizing leadership}

This theme recounted how leadership roles were legitimized given the needs to deploy organizational efforts during the campaign and how this impacted and sometimes challenged trans women's social networks. Within this community, a recognizable leadership figure had been that of the trans-madre (transmother)-(usually) older trans women who share cross-generational knowledge with younger and/or new members of the community (Quote 10) and are often imbued with a psychological characteristic of care and affection (Quote 11). Other trans women, while not identified as madres, were recognized as leaders in their houses for being responsible (Quote 12) or having previous 
experience with community organization. They were called amigas (friends) or encargadas (the ones in charge). The campaign sought to leverage these existing forms of leadership, and these trans women who were already perceived as responsible and dependable by their housemates-i.e., those considered madres, amigas, and encargadas-were chosen to be lideresas (Quotes $13 \& 14)$. As a result, five madres, two amigas, and four encargadas became the eleven lideresas.

Lideresas were responsible for implementing and managing the campaign activities at each house (e.g., communal pots, distributing and delivering groceries, managing the house budget). This produced a change within the trans women's social organization. Madres, amigas, and encargadas, while still identified as leadership figures, had a more horizontal relationship with their trans-daughters or housemates, grounded in respect and affection. However, because lideresas became institutionally legitimized as leaders and had managing and decision-making capacities, a more noticeable power differential was created between them and the other trans women.

These responsibilities related to the management of tangible aid also challenged the community's norms of trust, as lideresas had to guarantee transparency when distributing the donations and buying produce. They employed different strategies to involve the community in this process, such as reporting the houses' income and expenses (Quotes 15 \& 16); nevertheless, there was a sense of apprehension and a vigilant attitude among some of the trans women regarding the lideresas actions (Quote 17). The legitimization of this role did not only lead to new responsibilities, but because lideresas were representing their respective communities, they became subject to accountability and public scrutiny.

\section{Bridging relationships in the LGBT+ community and beyond}

This theme revealed how trans women leveraged social relationships with other groups across distinct levels of power to resist precarity. An important linkage of "bridging" relationships-inter-group relations of respect, trust, and mutuality (Szreter \& Woolcock, 2004)-was formed between lideresas, the campaign organizers, and other members of the LGBT+ community to assure the campaign's sustainability. First, lideresas, while part of the trans women's social network, became the links between the organizers and the community, transmitting their needs and implementing the proposed measures. Second, the organizers helped bridge trans women with more privileged sections of the middle class LGBT+ community, which led to LGBT+ owned businesses organizing fund-raising events and giving part of their proceeds to the campaign. Additionally, social media influencers associated with the LGBT+ community disseminated the campaign's information through their networks. 
The collaborative relationship between trans women and the campaign organizers also helped link the former with media outlets that contributed to making their struggles more visible (Quote 18). Because Peruvian media has historically perpetuated harmful stereotypes of trans individuals (Cosme, Jaime, Merino, \& Rosales, 2007) (Quote, p. 19), lideresas and the organizers worked together to ensure that articles and television segments about the campaign positively portrayed the trans women community (Quote 20). This contributed to widening the campaign's scope, sustaining donations, and setting a precedent for positive representations of LGBT+ people on Peruvian mainstream media.

\section{Discussion}

This study underscores the importance of community-based resistance strategies among trans women for reducing the impact of social vulnerabilities and failing infrastructural conditions generated and/or exacerbated by the COVID-19 pandemic. Understood through the construct of social capital, data highlighted the importance of social cohesion to ameliorate increasing levels of precarity (bonding social capital), community leaders as key links for connecting different networks (bridging social capital), and unified efforts of groups with common values (trans women and LGBT+ organizations) to influence formal institutions (linking social capital). Although presented separately, these forms of social capital were considerably intertwined. On the one hand, lideresas, beyond bridging social capital, emerged as a form of bonding capital, as they articulated organizational efforts within the community, as well as challenged social cohesion and trust norms. On the other hand, bonding capital (i.e., social cohesion to resist institutionalized violence) contributed to influencing institutions across power differentials (i.e., police department policies regarding trans people and media representations of trans individuals). Overall, results paralleled existing findings from trans women communities in Peru (Clark et al., 2020; Maiorana et al., 2016; Perez-Brumer et al., 2017) and globally (e.g., Hwahng et al., 2019; Kaplan, El Khoury, Wehbe, Lize, \& Mokhbat, 2020; Stanton, Ali, \& Chaudhuri, 2017).

Barriers to community organizing efforts were identified, such as difficulties negotiating cultural differences among individuals from different geographic regions, which has been reported as a limitation toward achieving a unified community among trans women (Clark et al., 2020), and declining levels of social interactions within trans-houses. Additionally, the legitimization of a leadership role that created noticeable power differential between trans women, while key for overcoming the difficulties associated with the pandemic, also challenged community trust norms. This constitutes a constraint for mobilizing toward more articulated political goals and reflects a broader systemic issue with democracy and authority in Peruvian 
society. Declining trust relations toward leadership figures are a feature of unequal and hierarchical societies (Szreter \& Woolcock, 2004), such as Peru, which is characterized by growing levels of within-regions economic inequality (Castillo, 2020) and a fragile democratic system (Levitsky \& Ziblatt, 2018). This has particularly negative consequences for those most affected by social marginalization, as it hinders their ability to form community networks and establish relationships with other groups higher up the social status hierarchy (Szreter \& Woolcock, 2004).

Findings from this study are limited by its reliance on mostly observational data of group dynamics and two focus groups with a small number of participants, thus it was not possible to capture nuances and deeper meanings relating to the way trans women understood and resisted the pandemic. Additionally, it focused on the experiences of a particular community of trans women marked by intersecting social and economic marginalization and living in a specific urban setting, which likely differs from the experiences of trans women from higher socioeconomic backgrounds and/or different regions. However, given critiques of transgender scholarly work that conceptualizes the diversity of trans lives into a monolithic community (Namaste, 2000), there is a need for further studies with larger and more diverse samples to elucidate the impact of the ongoing pandemic on Peruvian transgender communities.

Given these findings and the previous literature (e.g., Perez-Brumer et al., 2017), organizations and advocacy programs that seek to support trans women should leverage on the existing resources embedded in the community's networks and foster modes of self-organization, trust relationships, and community-based leadership.

\section{Notes}

1. "Trans" is employed as an umbrella term for persons whose gender identity, expression or behavior differs from what is culturally associated with the sex they were assigned at birth (American Psychological Association, 2014). Trans women (mujeres trans) was the category used by this group to identify themselves as a collective composed of femaleidentified and female-presenting individuals.

2. Large colonial houses, most in dilapidated conditions, which have been modified to accommodate various people in small rooms.

\section{Acknowledgments}

The authors thank Lucila Rozas, Emilia Fernández, Roxana Núñez and two anonymous reviewers for their thoughtful comments on earlier versions of this manuscript. Our deepest appreciation goes to the trans women community of Lima Centro. 


\section{Disclosure statement}

The authors report no potential conflict of interest

\section{ORCID}

Diego Garcia-Rabines (D) http://orcid.org/0000-0001-7960-2597

Bruno Bencich (D) http://orcid.org/0000-0002-5193-4298

\section{References}

Alvarez, B., Arias, M., Cuba, L., Mendoza, I., Perez, G., Ramos, A., ... Zeron, N. (2020). Resistir y vivir: Enfrentando la violencia por prejuicio institucional del Estado peruano. Centro de Promoción y Defensa de los Derechos Sexuales y Reproductivos. Lima, Peru: PROMSEX. Retrieved from https://promsex.org/wp-content/uploads/2020/04/Resistir-y-vivir.pdf

American Psychological Association. (2014, December 1). Answers to your questions about transgender people, gender identity, and gender expression. Retrieved from http://www.apa. org/topics/lgbt/transgender

Braun, V., \& Clarke, V. (2006). Using thematic analysis in psychology. Qualitative Research in Psychology, 3(2), 77-101. doi:10.1191/1478088706qp063oa

Braun, V., \& Clarke, V. (2019). Reflecting on reflexive thematic analysis. Qualitative Research in Sport, Exercise and Health, 11(4), 589-597. doi:10.1080/2159676X.2019.1628806

Castillo, L. (2020). Regional dynamics of income inequality in Peru. Central Reserve Bank of Peru. Retrieved from https://www.bcrp.gob.pe/docs/Publicaciones/Documentos-de-Trabajo /2020/documento-de-trabajo-004-2020.pdf

Clark, J. L., Perez-Brumer, A. G., Reisner, S. L., Salazar, X., McLean, S., Huerta, L., ... Lama, J. R. (2020). Social network organization, structure, and patterns of influence within a community of transgender women in Lima, Peru: Implications for biomedical HIV prevention. AIDS and Behavior, 24(1), 233-245. doi:10.1007/s10461-019-02506-8

Cosme, C., Jaime, M., Merino, A., \& Rosales, J. (2007). La imagen in/decente. Diversidad sexual, prejuicio y discriminación en la prensa escrita peruana. Lima, Peru: IEP Instituto de Estudios Peruanos.

Haraway, D. (1988). Situated knowledges: The science question in feminism and the privilege of partial perspective. Feminist Studies, 14(3), 575-599. doi:10.2307/3178066

Hwahng, S. J., Allen, B., Zadoretzky, C., Barber, H., McKnight, C., \& Des Jarlais, D. (2019). Alternative kinship structures, resilience and social support among immigrant trans Latinas in the USA. Culture, Health \& Sexuality, 21(1), 1-15. doi:10.1080/13691058.2018.1440323

Kaplan, R. L., El Khoury, C., Wehbe, S., Lize, N., \& Mokhbat, J. (2020). Pilot results from the first HIV/AIDS intervention among transgender women in the Middle East: Gender affirmation and social support from within trans communities in Beirut, Lebanon. AIDS Research and Human Retroviruses, 36(6), 501-512. doi:10.1089/AID.2019.0203

Levitsky, S., \& Ziblatt, D. (2018). How democracies die. New York, USA: Broadway Books.

Maiorana, A., Kegeles, S., Salazar, X., Konda, K., Silva-Santisteban, A., \& Cáceres, C. (2016). 'Proyecto Orgullo,' an HIV prevention, empowerment and community mobilisation intervention for gay men and transgender women in Callao/ Lima,Peru. Global Public Health, 11 (7-8), 1076-1092. doi:10.1080/17441692.2016.1161814

Namaste, V. (2000). Invisible lives: The erasure of transsexual and transgendered people. Chicago: University of Chicago Press. 
Namaste, V. (2009). Undoing theory: The "Transgender question" and the epistemic violence of Anglo-American feminist theory. Hypatia, 24(3), 11-32. doi:10.1111/j.15272001.2009.01043.x

Oporto, G. J. (2018). La “erradicación” de homosexuales y personas trans: Análisis de los planes de seguridad ciudadana de Lima Metropolitana y sus distritos. In B. Alvarez (Ed.), Informe temático de personas lesbianas, gays, bisexuales y trans (LGBT) Derecho a la igualdad de las personas LGBT en el Perú: Perspectivas jurídicas y políticas (pp. 154-166). Lima, Peru: PROMSEX. Retrieved from https://promsex.org/publicaciones/informe-lgbt-2018-derecho -a-la-igualdad-de-las-personas-lgbt-en-el-peru-perspectivas-juridicas-y-politicas/.

Perez-Brumer, A. G., Reisner, S. L., McLean, S. A., Silva-Santisteban, A., Huerta, L., Mayer, K. H., ... Lama, J. R. (2017). Leveraging social capital: Multilevel stigma, associated HIV vulnerabilities, and social resilience strategies among transgender women in Lima, Peru. Journal of the International AIDS Society, 20(1), 21462. doi:10.7448/IAS.20.1.21462

PNP rechaza discriminación: sancionarán a los agentes que intervinieron a mujeres trans. (April 4, 2020). La República. Retrieved from https:/larepublica.pe/sociedad/2020/04/04/ coronavirus-en-peru-pnp-rechaza-discriminacion-y-anuncia-sancion-a-los-agentes-queintervinieron-a-dos-mujeres-trans-video/

Presidencia del Consejo de Ministros (2020, April 2). Decreto Supremo que modifica el Articulo 3 del Decreto Supremo No 051-2020-PCM, que prorroga el Estado de Emergencia Nacional declarado mediante Decreto Supremo No 044-2020-PCM, por las graves circunstancias que afectan la vida de la Nación a consecuencia del COVID-19. Supreme Decree 057-2020-PCM. Diario Oficial El Peruano. Retrieved from https://cdn. www.gob.pe/uploads/document/file/574872/DS_057-2020-PCM.pdf

Salazar, X., Núnez-Curto, A., Villayzán, J., Castillo, R., Benites, C., Caballero, P., \& Cáceres, C. F. (2016). How Peru introduced a plan for comprehensive HIV prevention and care for TW. Journal of the International AIDS Society, 19(3), 20790. doi:10.7448/ IAS.19.3.20790

Silva Santisteban, A., Raymond, H. F., Salazar, X., Villayzán, J., Leon, S., McFarland, W., \& Cáceres, C. F. (2012). Understanding the HIV/AIDS epidemic in transgender women of Lima, Peru: Results from a sero-epidemiologic study using respondent driven sampling. AIDS and Behavior, 16(4), 872-881. doi:10.1007/s10461-011-0053-5

Speed, S. (2008). Forged in dialogue: Toward a critically engaged activist research. In C. R. Hale (Ed.), Engaging contradictions: Theory, politics, and methods of activist scholarship (pp. 213-236). Berkeley: University of California Press. doi:10.1525/9780520916173

Stanton, M. C., Ali, S., \& Chaudhuri, S. (2017). Individual, social and community-level predictors of wellbeing in a US sample of transgender and gender non-conforming individuals. Culture, Health \& Sexuality, 19(1), 32-49. doi:10.1080/13691058.2016.1189596

Szreter, S., \& Woolcock, M. (2004). Health by association? Social capital, social theory, and the political economy of public health. International Journal of Epidemiology, 33(4), 650-667. doi:10.1093/ije/dyh013 